\title{
O DIVÃ DE GOETHE NO BRASIL: UMA DANÇA DA POESIA, HARMÔNICA NO TUMULTO
}

\author{
Marcus V. Mazzari $1^{1}$ \\ 1'Universidade de São Paulo, São Paulo, São Paulo, Brasil
}

\begin{abstract}
Resumo: Este ensaio enfoca o mais amplo ciclo lírico de Johann Wolfgang von Goethe sob o ensejo da publicação, em 2020, de sua primeira tradução integral em português, assinada por Daniel Martineschen: Divã ocidento-oriental (Estação Liberdade). Posição de destaque nas considerações sobre os procedimentos mobilizados pelo tradutor ocupam os poemas "Anelo abençoado" (Livro do Cantor"), também traduzido por Manuel Bandeira, e "Gingo biloba" (Livro de Zuleica"). Nesse contexto, o ensaio recorre ainda à tipologia tripartite sobre a arte da tradução que Goethe esboçou no texto em prosa ("Notas e ensaios para uma melhor compreensão do Divã") que acompanha os 12 livros de poemas. Por fim procurou-se relacionar o Divã à concepção goethiana de Literatura Mundial (Welttiteratur), na qual entraram também canções "brasileiras" em língua tupi. Palavras-chave: Goethe; Divã ocidento-oriental; Hafez; Teoria da Tradução; Weltliteratur
\end{abstract}

\section{GOETHE'S WEST-EASTERN DIVAN IN BRAZIL: A DANCE OF THE SPHERES, HARMONIOUS IN TURMOIL}

\begin{abstract}
This essay focuses on Johann Wolfgang von Goethe's broadest lyrical cycle following the publication in 2020 of its first complete translation into Portuguese, signed by Daniel Martineschen: Divã ocidento-oriental (Estação Liberdade). The poems "Blessed longing" (in "Book of the Singer"), also translated by Manuel Bandeira, and "Gingo biloba" (in "Book of Zuleica"), occupy a central position in the theoretical considerations about the procedures used by the translator. In this context, this essay also explores the tripartite typology of translation that Goethe outlined in the prose text ("Notes and essays for a better understanding
\end{abstract}


of the Divan"), appended to the 12 books of poems. Finally, this essay relates the genesis of the Divan to the Goethian conception of World Literature (Weltliteratur), into which "Brazilian" songs in Tupi language were also included.

Keywords: Goethe; West-eastern Divan; Hafez; Translation Theory; World Literature

"Arco-íris diante de um fundo cinza-escuro": a recepção da obra goethiana no Brasil do século XXI talvez possa ser ilustrada com essa imagem que o poeta empregou numa carta dirigida ao seu amigo berlinense Carl Friedrich Zelter. Refugiado então na cidadezinha de Dornburg, Goethe elaborava o luto pela morte do duque Carl August, com quem tivera estreita convivência ao longo de meio século, e a detalhada descrição dos jardins e vinhedos projetados pelo recém-falecido converge e se sintetiza por fim no símbolo de "cores intensificadas, como o arco-íris diante de um fundo cinza-escuro". 1

Com efeito, a presença do autor do Fausto em nosso país não faz senão intensificar-se, a despeito do cenário "cinza-escuro" sob um governo obscurantista e hostil à cultura, eleito graças à propagação do ódio e de Fake News e que teve, entre seus altos funcionários, um Secretário da Cultura plagiador de Joseph Goebbels e um Ministro da Educação que se notabilizou por discursos peçonhentos, num deles convertendo o autor de que deriva o universal adjetivo "kafkiano" em prato árabe.

A contrapelo desse panorama sombrio, a obra de Goethe vem afirmando-se entre nós com expressiva pujança, para a qual somente a editora UNESP contribuiu com três títulos de imensa envergadura: Viagem à Itália (2018), De minha vida: Poesia e verdade (2017) e, de Johann Peter Eckermann, Conversações com Goethe

${ }^{1}$ Datada de 10 de julho de 1828, essa carta é considerada pelo crítico Albrecht Schöne como "uma das grandes respostas à condição mortal do ser humano" (ver a esse respeito o ensaio " $O$ humano que jamais nos abandona’. A obra epistolar de Goethe” (225-252)). A imagem de um "magnífico arco-íris” destacando-se de um fundo cinza aparece também no romance Os anos de aprendizado de Wilhelm Meister, abrindo com grande força simbólica o $7^{\circ}$ livro. 
nos últimos anos de sua vida (2016), respectivamente em tradução de Wilma Patricia Maas, Mauricio Mendonça Cardozo e Mario Luiz Frungillo. Essa pujança estendeu-se, com a tragédia Fausto e o romance Os sofrimentos do jovem Werther, ao mundo dos quadrinhos (Editora Peirópolis); também novos estudos sobre a obra goethiana foram publicados recentemente e traduções inéditas vieram a lume, como o tratado sobre $A$ metamorfose das plantas e outros textos botânicos, por Fábio Mascarenhas Nolasco, mais dois Werther, assinados por Claudia Dornbusch e Mauricio Cardozo ${ }^{2}$, ou os dramas por assim dizer "menores": O Grande Cophta e, em 2020, Götz von Berlichingen da mão de ferro, por Felipe Vale da Silva.

Ainda em 2020, um ano após ter-se completado o segundo centenário do West-östlicher Divan (oito anos depois, em 1827, Goethe publicaria uma edição ampliada), surge sua primeira tradução integral em língua portuguesa, assinada por Daniel Martineschen (São Paulo, Estação Liberdade). Apresentada originalmente no âmbito de um trabalho de doutorado ("O lugar da tradução no West-östlicher Divan de Goethe"), defendido na Universidade Federal do Paraná em 2016, essa tradução traz um título - Divã ocidento-oriental - que de imediato pode causar certa estranheza com o adjetivo "ocidento", não consignado nos dicionários de língua portuguesa, tanto os mais recentes (Houaiss ou Aurélio), como os mais antigos, como o Bluteau ou o Morais, dos séculos XVIII e XIX.

Esse eventual estranhamento derivado do adjetivo composto "ocidento-oriental” talvez possa despertar no leitor a impressão

\footnotetext{
${ }^{2}$ Respectivamente publicados em dezembro de 2020 e junho de 2021 pelas editoras Antofágica e Companhia das Letras. Esse romance de estreia de Goethe está à disposição do leitor brasileiro em várias traduções, entre as quais a de Galeão Coutinho (Abril Cultural, 1973); Erlon José Paschoal (Clube do Livro, 1988, e, posteriormente, Estação Liberdade, 1999, com posfácio de Willi Bolle); Marion Fleischer (Martins Fontes, 1994); Leonardo César Lack (Nova Alexandria, 1999); Marcelo Backes (L\&PM, 2001); Claudia Cavalcanti (Martin Claret, 2014); também a tradução anônima (versão de 1774 do Werther), com introdução de Oliver Tolle (Hedra, 2006); a tradução/adaptação de Ângelo A. Stefanovitz (Scipione, 1998); Ary de Mesquita (Ediouro, sem indicação de data); e, ainda, a edição da Organização Simões (1957, sem indicação de tradutor).
} 
de que ele está prestes a entrar numa oficina tradutória experimental e vanguardista, fundamentada em concepções próximas, por exemplo, às de Haroldo de Campos, que assenta todo seu trabalho de tradutor - ou de "transcriador" e mesmo de "transluciferador mefisto-fáustico", em seus próprios termos - sobre o pilar de uma “operação paronomástica generalizada, de Jakobson, centrada no princípio de equivalência da função poética". ${ }^{3}$ Mas já a leitura dos poemas do primeiro dos doze livros em versos que compõem esse ciclo ocidental-oriental - o "Livro do cantor": Moganni Nameh, na designação persa igualmente empregada por Goethe para cada livro - não confirma tal impressão, e ao chegar no "Posfácio" redigido por Martineschen, o leitor ficará sabendo que o tradutor encontrou "auxílio" (expressão sua) antes na tradução do Fausto realizada por Jenny Klabin Segall ao longo de três décadas.

No geral, são sóbrios os recursos mobilizados pelo tradutor Daniel Martineschen para transpor os poemas goethianos ao português, começando pelo empenho em reproduzir com rigor e fidelidade o esquema métrico, rímico e estrófico do original, consultado na excelente edição crítica e comentada preparada por Hendrik Birus para a chamada Editora dos Clássicos Alemães (Deutscher Klassiker Verlag), publicada em 2010. Via de regra, o tradutor procurou reproduzir o verso de quatro acentos (que no posfácio é designado de maneira um tanto problemática como "tetrâmetro") e em ritmo trocaico - sucessão de acentos fortes (sílaba tônica), e fracos (átona) - por meio da redondilha maior (sete sílabas), enquanto que o verso alemão "hexassílabo", como se exprime o tradutor em outro momento do posfácio, foi transposto através das cinco sílabas da redondilha menor. ${ }^{4}$ Aparentemente ocorreria assim

\footnotetext{
${ }^{3}$ Ver, na terceira parte de seu estudo Deus e o diabo no Fausto de Goethe, o Post Scriptum “Transluciferação Mefistofáustica”, que se fecha com as palavras: "Flamejada pelo rastro coruscante de seu Anjo instigador, a tradução criativa, possuída de demonismo, não é piedosa nem memorial: ela intenta, no limite, a rasura da origem: a obliteração do original. A essa desmemória parricida chamarei 'transluciferação'” (209).

${ }^{4}$ No geral, recorre-se na versificação alemã às designações gregas "trímetro",
} 
a subtração sistemática, em relação ao original, de uma sílaba, mas ao se valer com frequência de sinalefas e elisões, Martineschen ganha a possibilidade de corresponder adequadamente à estrutura métrica (e por vezes mesmo rítmica) dos versos goethianos. Em si essa dilatação do número de sílabas pode não constituir propriamente uma vantagem no âmbito de um gênero (a lírica) que se distingue pela condensação; no entanto, Martineschen conquistou desse modo uma maior flexibilidade para a transposição do eventual "sentido" presente nos poemas em que o poeta "ocidental" dialoga com seus colegas "orientais", sobretudo o seu "gêmeo" persa do século XIV Hafez, conforme se formula na terceira estrofe do poema "Ilimitado", com seu ritmo predominantemente trocaico de quatro acentos no original, e que na tradução oscila entre sete e (com a duplicação de "contigo" no verso citado) nove sílabas poéticas: "E pode o mundo se afundar, / Hafez, contigo, contigo apenas / disputarei! Prazer e penas / sejam a nós, gêmeos, plenas! / Como tu beber e amar / será o orgulho, a minha sina!" 5

Se o intertexto levantino de Goethe - "Admite! Os poetas do Oriente / são maiores que os do Ocidente", lemos no "Livro dos

\footnotetext{
"tetrâmetro", "pentâmetro", "hexâmetro" quando se trata de textos da própria literatura grega. Na versificação alemã vigora o sistema de sílabas acentuadas (Hebungen) e não acentuadas (Senkungen), tendendo-se por isso a falar de versos de três, quatro, cinco acentos. Trata-se de uma diferença importante em relação à versificação em português e em outras línguas românicas, que optam pela contagem das sílabas poéticas (e não gramaticais) - falando-se assim em hexassílabo, decassílabo etc.

${ }^{5}$ O poema "Ilimitado" conta também, entre nós, com uma tradução de Ruy Fausto, publicada na edição de julho de 2014 da revista Fevereiro: "Que concluir não possas, te faz grande, / E que jamais comeces, teu destino. / Teu canto gira qual celeste esfera, / Começo e fim perpetuamente o mesmo, / E o que oferece o meio, é manifesto, / É o que está no final e era o começo. // És, da alegria, a pura fonte poética, / Vagas e vagas, de ti, fluem sem conta. / A boca, aos beijos sempre pronta, / Canto profundo que, suave, eflui, / De beber, sempre ávida a garganta, / Um coração sem mal que se derrama. // Naufrague o mundo inteiro! / Hafis, a ti, só a ti, desafio. / Gêmeos, em comum nos valham / o prazer e a pena! / Que o beber e o amar, para mim, sejam / - o que são para ti - orgulho e vida. // Ressoa, ó canto, à própria flama! / Porque és mais velho, porque és mais novo".
} 
provérbios" - já estava muito distante do leitor alemão e europeu das primeiras décadas do século XIX, tanto mais remoto ele se encontra em relação ao leitor brasileiro do século XXI e, nesse sentido, talvez se possa dizer que lhe seriam muito bem-vindas notas breves e objetivas que elucidassem alusões e referências de que os poemas são pródigos. É certo que o próprio poeta pospôs ao seu ciclo lírico um $13^{\circ}$ livro em prosa ("Notas e ensaios para melhor compreensão do Divã ocidento-oriental") justamente para facilitar a orientação do leitor nesse diálogo poético que se estende por sobre cinco séculos; contudo, mesmo assim o leitor terá de pesquisar muito por conta própria a fim de captar em níveis mais profundos o sentido de certos poemas, e isso não só no tocante a conceitos e elementos do mundo islâmico, como se manifestam em dois poemas do "Livro de Hafez" intitulados "Fátua" (espécie de parecer sobre questão controversa emitido por um mufti, erudito islâmico), mas por vezes também em relação à cultura ocidental: por exemplo, quando Goethe critica a hipocrisia religiosa ao delinear um paralelo ("Livro do mau humor") entre as adversidades impostas a Hafez e Ulrich Hutten por "hábitos marrons e azuis", na metonímia original, traduzida de maneira explicativa por "monges cristãos e muçulmanos". (Uma elucidação concisa sobre Ulrich Hutten, humanista e poeta alemão que viveu entre 1488 e 1523, seria certamente bastante útil ao leitor brasileiro nesse poema; e essa mesma constatação vale para tantos outros versos.)

\section{"Anelo abençoado" e "Gingo biloba"}

Como sabido, Divã é um substantivo de origem persa (dīwān) e significa, em sentido literário, "ciclo" ou "coletânea". De certo modo, esse conjunto de poemas inspirados em Hafez e vários outros poetas persas e árabes, pode ser visto como pendant "oriental" às Elegias romanas, escritas após a viagem italiana empreendida pelo poeta entre setembro de 1786 e abril de 1788 e que são publicadas integralmente apenas em 1914. Entre os poemas mais conhecidos 
do Divã está Selige Sehnsucht, título que Manuel Bandeira, ao traduzi-lo, condensou numa única palavra: "Anelo". Martineschen o traduz por "Anelo abençoado", enquanto a versão do português Paulo Quintela traz "Nostalgia de bem-aventurança". ("Nostalgia" é também a opção do famoso tradutor espanhol Rafael Cansinos Assens: "Dichosa nostalgia". ${ }^{6}$ )

Há ainda outras traduções desse poema para o português, mas não será demérito para nenhuma delas, incluindo-se a de Martineschen, afirmar que o autor do "Gazal em louvor de Hafiz" - um dos poemas mais musicais de toda a lírica brasileira - colocou-se num patamar incomparável ao dar aos heptassílabos de seu "Anelo" o ritmo melífluo, sem tropeço algum, que pode ser exemplificado com a última das cinco estrofes: “Morre e transmuda-te': enquanto / Não cumpres esse destino, / És sobre a terra sombria / Qual sombrio peregrino". ${ }^{7}$ A tradução de Martineschen reproduz fielmente, ao contrário da bandeiriana, a duplicação do pronome demonstrativo ("isto") presente no original sob a forma de das e dieses, mas perde a importante correspondência entre "hóspede turvo" e "terra sombria", mediante a qual os termos se reiteram e intensificam: "Se isto não te habita, / isto: morre e te transforma! / Não passas de visita / Na terra sem forma". Já Quintela preserva essa correspondência ("conviva turvo" e "trevas", uma vez que transforma em substantivo o adjetivo goethiano que qualifica "ter-

\footnotetext{
${ }^{6} \mathrm{Na}$ versão de Rafael C. Assens (1882 - 1964) a última estrofe de Selige Sehnsucht diz: “Que mientras en ti cumplido / no veas el ‘¡Muere y transfórmate!', / serás en la oscura tierra / no más que un huésped borroso / que vaga entre las tinieblas". Divan de Occidente y Oriente, tradução integral e copiosamente anotada do ciclo, encontra-se no primeiro dos três tomos das "Obras completas" de Goethe, perfazendo cerca de seis mil páginas. Verdadeiro polímata, Assens apresenta como tradutor uma produção prodigiosa, englobando, na literatura árabe, $O$ Alcorão e As mil e uma noites, também as "obras completas" de Dostoiévski e Balzac e ainda vários títulos de Schiller, Maquiavel e outros autores.

${ }^{7}$ Para eventual comparação com o original alemão: Und solang du das nicht hast, / Dieses: Stirb und werde! / Bist du nur ein trüber Gast / Auf der dunklen Erde. Em tradução literal: "E enquanto não o tiveres, / Este: Morre e torna-te! / Serás apenas um hóspede turvo / Na terra sombria”.
} 
ra"), mas conferindo um peso excessivo ao fecho do poema com o conceito "terra-mãe": "E enquanto não entenderes / Isto: - Morre e devém! -, / Serás só turvo conviva / Nas trevas da terra-mãe".

Oferece-se aqui o ensejo para observar que em seu Divan - e concluindo o "Livro do cantor", o primeiro do ciclo - Goethe fez seguir a esse poema (não se sabe se após sua conclusão ou meses depois) uma quadra sem vínculo direto com as estrofes anteriores, mas antes preparando a transição para o próximo livro, o de "Hafez" (Hafis Nameh). Na recepção crítica do Divan esse fato nem sempre foi percebido com clareza e o próprio Martineschen, ao comentar em seu posfácio a versão bandeiriana, cita essa quadra autônoma como pertencente a "Anelo", embora ela não se encontre, certamente por decisão do próprio Bandeira, na seção "Poemas traduzidos" das várias edições da Estrela da vida inteira: "Como vem da cana o sumo / Que os paladares adoça, / Flua assim da minha pena / Flua o amor o quanto possa". ${ }^{8}$

Outro célebre poema do Divã foi inspirado por um oriente ainda mais remoto do que as terras de Chiraz ou Samarcanda: "Gingo biloba", título que alude à folha bilobada da árvore Ginkgo (por razões sonoras Goethe omitiu o "k" na terceira versão do poema), originária da China e do Japão. ${ }^{9}$ Como em “Anelo", a mensagem

${ }^{8} \mathrm{Na}$ edição de dezembro de 1949 do suplemento literário Autores e Livros, publicado entre 1941 e 1950 pelo jornal $A$ Manhã (RJ), a tradução de Bandeira, apresentada num único bloco, traz esses versos (página 182) como pertencentes ao poema "Anelo". Percebendo depois a impropriedade (pois essa quadra apenas preludia o motivo do "amor" que irá fluir docemente da "pena" de Hafez no livro seguinte, Hafis Nameh), o poeta-tradutor excluiu-os já da $3^{\text {a }}$ edição de seus Poemas traduzidos (1956, Coleção Rubaiyat) e, consequentemente, da $1^{\text {a }}$ edição de sua Estrela da vida inteira, publicada em 1966.

${ }^{9}$ Se na obra goethiana árvores revestem-se de alto significado simbólico (que se pense na importância que um par de tílias adquire no último ato do Fausto), vale lembrar que um exemplar da "árvore do oriente", celebrada no Divã, transformouse em símbolo de resistência por ter sobrevivido ao desastre nuclear em Hiroshima. Situado a apenas 800 metros do epicentro da explosão de seis de agosto de 1945, o gingko de Hiroshima havia sido aparentemente destruído por completo, como tudo o mais. Contudo, na primavera do ano seguinte a árvore voltou a brotar. Vale lembrar nesse contexto que Goethe fecha o $1^{\circ}$ livro de seu romance de velhice Os anos 
desse poema do "Livro de Zuleica", nada dizendo ao "vulgo", está destinada a edificar os "sábios". Martineschen traduz exemplarmente em redondilhas maiores, valendo-se de sinalefas, mas também de hiato no quarto verso, o ritmo alemão trocaico de quatro acentos:

Folha de árvore do Oriente que no meu jardim se faz, dá-me a ver sentido ausente que aos sábios só apraz.

Será apenas um vivo ser?

Que de si em si se parte, serão dois? que, no colher, dão em um sem que se aparte?

Pra atender a tais questões alcancei um senso azado; não vês tu nestas canções que sou Um e duplicado?

Na primeira estrofe temos a apresentação da "folha" da árvore que, do Oriente, foi transplantada ao jardim do poeta, sugerindo-se uma correlação com a "folha" de papel que, contendo a terceira versão de "Gingo biloba", integrou-se ao "florilégio" ocidental-oriental de Goethe - ou "antologia”, para usar esse substantivo com conotações botânicas, já que oriundo do grego anthos, "flor". Nas duas estrofes seguintes acumulam-se interrogações sobre a natureza da folha e a identidade do poeta, tendo por pano de fundo o mo-

de peregrinação de Wilhelm Meister com a imagem de uma árvore enquanto símbolo de esperança e resistência: "Por vezes nosso destino se assemelha a uma árvore frutífera no inverno. Quem poderia pensar, diante de seu triste aspecto, que na próxima primavera esses galhos inteiriçados, esses ramos espinhosos irão vicejar, florescer e dar novamente frutos; mas nós esperamos isso, nós o sabemos". 
tivo do duplo e da duplicidade. A folha bipartida parece assomar enquanto metáfora simbólica da simbiose entre os "gêmeos" Goethe e Hafez e, por extensão, entre o Ocidente e o Oriente: "Quem conhece a si e aos outros / também haverá de reconhecer: / Oriente e Ocidente / não podem mais ser separados". ${ }^{10}$ Ou entre Goethe e "Hatem", nome tomado a dois poetas árabes (citados num poema em que o tradutor insere arbitrária e surpreendentemente o termo leixa-pren, inexistente no original ${ }^{11}$ ) e assumido pelo poeta ocidental para dialogar com Zuleica, por sua vez a máscara persa de Marianne von Willemer, que Goethe encontrou durante uma viagem pela região do Reno em 1814 e que, entrando com grande virtuosismo no jogo erótico-lírico, contribuiu com algumas "folhas" para o herbário poético publicado em $1819 .{ }^{12}$

Nesse sentido, essa folha que se divide em duas, ou que ganhou sua unidade pela união de duas, simboliza igualmente o enlace lírico de Hatem e Zuleica. As três estrofes de "Gingo biloba" também fo-

${ }^{10}$ Wer sich selbst und andere kennt / Wird auch hier erkennen: / Orient und Occident / Sind nicht mehr zu trennen. Anotados por Goethe durante o trabalho no Divan, esses versos não foram, porém, incorporados ao ciclo. (Justamente por isso Guimarães Rosa se confunde ao citá-los no célebre diálogo de janeiro de 1965 com Günter Lorenz.)

${ }^{11}$ Os dois poetas árabes Hatem Thai e Hatem Zograi são citados no poema do "Livro de Zuleica” que diz nos quatro últimos versos, em tradução literal: “Tomar, ofertar as dádivas da felicidade / Sempre será um imenso prazer. / Deliciar-se mutuamente em amor / Será o enlevo do paraíso" (Zu nehmen, zu geben des Glückes Gaben / Wird immer ein gros Vergnügen sein. / Sich liebend aneinander zu laben / Wird Paradieses Wonne sein). Na tradução de Martineschen: "Leixa-pren da sorte presente / grande prazer há de ser. / Refrescar-se um no outro amante: / o Paraiso há de ser".

${ }^{12}$ A participação de Marianne von Willemer no Divã, com a autoria de três poemas do "Livro de Zuleica" ("Bendita teu amor me faz"; "O que é o movimento?"; e "Ah, das tuas úmidas asas"), veio à luz apenas em 1869, quando o germanista Herman Grimm publica o estudo "Goethe und Suleika". Grimm reporta-se a uma conversa com M. v. Willemer dez anos antes, durante a qual a mulher lhe revelou ter escrito, ela mesma, aqueles poemas (que Goethe incorporou ao ciclo com leves alterações), mostrando-lhe as cartas trocadas com Goethe que documentavam a autoria. A revelação tardia desse fato deve-se ao pedido expresso feito pela própria autora dos poemas. 
ram traduzidas por Paulo Quintela, mas em Portugal há ainda a bela versão de João Barrento, reproduzida abaixo para que o leitor possa estabelecer eventual comparação com a tradução de Martineschen:

Esta folha, que o Oriente

Ao meu jardim confiou,

Dá a provar o secreto

Saber que o sábio formou.

É um ser vivo que em si

Mesmo em dois se dividiu?

Ou são dois que se elegeram

E o mundo neles $u m$ viu?

Dessas perguntas que fazes

Sentido certo te dou:

Não sentes nos cantos meus

Como eu uno e duplo sou? (334)

\section{Tipologia da Tradução}

A motivação crucial que lançou Goethe à elaboração desse Divã que se tornaria seu mais extenso volume lírico adveio da leitura intensa e reiterada, a partir de junho de 1814, do ciclo homônimo de Hafez, na tradução do diplomata e orientalista austríaco Hammer-Purgstall (1774 - 1856). O impacto dessa experiência foi de tal ordem que o poeta alemão se viu obrigado a reagir de modo produtivo ao novo mundo descortinado por Hafez, isto é, respondendo aos poemas persas com criações próprias. Do contrário, conforme anotou em um de seus escritos autobiográficos, "eu não poderia ter-me sustentado diante do poderoso fenômeno". ${ }^{13}$ Em torno da

${ }^{13}$ Na seção dedicada ao ano de 1815 em seus "Diários e Anuários" (Tag- und Jahreshefte), Goethe escreve: "Já no ano passado chegaram a mim os poemas 
leitura dessa tradução, Goethe catalisa toda sua ocupação anterior com a literatura e a cultura do Oriente, seus conhecimentos prévios de poetas árabes e persas e também o contato com o Antigo Testamento, como o texto "Israel no deserto" que, redigido em maio de 1797, é integrado agora às "Notas e ensaios para melhor compreensão do Divã". ${ }^{14}$

Não surpreende que, num dos capítulos dessa parte teórica, Goethe teça considerações sobre um aspecto essencial na constituição da Weltliteratur (Literatura Mundial, conceito que criará poucos anos depois): a tradução. Goethe propõe então uma tipologia tripartite da arte tradutória, sendo que o primeiro tipo diz respeito a uma tradução sempre em prosa, cuja dicção procuraria nivelar todas as peculiaridades do original. O poeta exemplifica com a versão bíblica de Lutero quão valiosa tal tradução por assim dizer homogeneizante pode revelar-se:

Apesar de a prosa eliminar por completo toda idiossincrasia de qualquer arte poética e rebaixar o entusiasmo poético a um mesmo nível, mesmo assim ela presta um grande ser-

completos de Hafez na tradução de Hammer, e se até então não me diziam muita coisa os textos isolados desse magnífico poeta, traduzidos e publicados aqui e ali em revistas, em conjunto eles tiveram sobre mim um impacto tanto mais vívido e, confrontado desse modo, precisei agir de maneira produtiva, do contrário eu não poderia ter-me sustentado diante do poderoso fenômeno" (514).

${ }^{14}$ Em outubro de 1775 Goethe traduziu o "Cântico dos cânticos" de Salomão ("a mais magnífica coleção de canções de amor criada por Deus", como escreveu ao seu amigo Johann H. Merck) e incorporou alguns de seus motivos ao manuscrito do Fausto (cena "Jardim").

O poeta também se interessou desde menino pela história do José bíblico e, segundo o relato de Poesia e verdade (117), em 1760 descreveu numa redação doze imagens que representavam essa história. Em sua autobiografia, Goethe fala ainda do desejo de desdobrar "em seus mínimos detalhes" a história de José, narrada na Bíblia de modo "demasiadamente breve" (174). Essa tarefa coube, entre 1933 e 1943, a Thomas Mann, que colheu em Goethe um estímulo suplementar para redigir a tetralogia José e seus irmãos, com a qual procurou "tirar o mito das mãos do fascismo intelectual e amoldá-lo à esfera do humano", conforme escreveu em 1941 ao filólogo e mitólogo Karl Kerényi. 
viço inicial, pois nos surpreende com o extraordinário do estrangeiro dentro de nosso aconchego nacional e de nosso cotidiano, de modo que, sem que saibamos como, fornecenos um ânimo mais elevado e verdadeiramente nos edifica. A tradução da Bíblia por Lutero vai produzir sempre um efeito desses (Goethe 403). ${ }^{15}$

O segundo tipo aparece designado como "paródico", concebido no puro sentido do termo, ou seja, desenvolvendo-se em "paralelo". O tradutor se transpõe inteiramente ao horizonte cultural do original, mas ao mesmo tempo apropriando-se do elemento estrangeiro por meio do que lhe é próprio e, assim, exprimindo o estrangeiro através dos recursos tradicionais de sua língua materna, de sua própria cultura. As valiosas traduções que Wieland fez da obra shakespeariana, enaltecidas também no romance Os anos de aprendizado de Wilhelm Meister, ofereceriam a ilustração para essa modalidade de tradução, à qual Goethe fez remontar algumas de suas reflexões posteriores sobre a arte da tradução. Como exemplo citem-se essas palavras anotadas sob a data de 20 de setembro de 1827 pelo chanceler von Müller (1779 - 1849), colaborador assíduo do poeta por vários anos, em seu livro Conversações com Goethe (publicado postumamente em 1870): “Durante a tradução não se deve entrar numa luta frontal com o idioma estrangeiro... Deve-se avançar até o intraduzível e respeitá-lo, pois é nele que residem o valor e o caráter de todo idioma" (150).

A terceira modalidade na tipologia proposta nas "Notas e ensaios" consistiria na tentativa de aproximar a tradução o mais rente possível ao texto original. Seria esse paradigma que sofre de início as maiores resistências, como mostra a recepção, observa Goethe, das transposições que Johann Heinrich Voss (1751 - 1826) fez das

${ }^{15}$ Divã ocidento-oriental. Guardadas as proporções, um exemplo dessa tradução em prosa homogeneizante, tal como visada por Goethe, pode ser encontrada na tradução em prosa que Jaime Bruna fez dos hexâmetros da Odisseia, publicada originalmente em 1968. 
epopeias homéricas; pois ao amoldar-se às particularidades do original, o tradutor fere muitas vezes o gosto de seus contemporâneos, não raro infringindo normas do "idioma de chegada". (Este seria também, valeria assinalar, o caso das traduções que Friedrich Hölderlin fez em 1804 das tragédias Édipo Rei e Antígona, de Sófocles, que "feriram" então o gosto estético de Goethe e Schiller e só foram devidamente reconhecidas em seu valor e originalidade no século $\mathrm{XX}$, em grande parte graças a encenações de Bertolt Brecht.)

Na perspectiva dessa tipologia, a tradução de Daniel Martineschen se inclinaria mais para aquela segunda espécie caracterizada como "paródica". Pois, como dito, os princípios que nortearam seu trabalho com o Divan goethiano estão muito distantes das concepções de um Haroldo de Campos, que não só empurram suas traduções - seja a da Ilíada ou de trechos do Fausto e da Comédia - para o terceiro campo, mas levam-nas ainda a ultrapassá-lo, com a proposta de uma "operação paronomástica generalizada" e a consequente hybris de converter o original (ver nota 4) em tradução de sua própria "transcriação" (ou "transiluminação", no caso de Dante, e "transluciferação mefisto-fáustica", no caso de Goethe).

O trabalho de Martineschen mostra-se, comparado com a sofisticada oficina tradutória de Haroldo de Campos, bem mais sóbrio: "Meu objetivo foi tentar traduzir o Divã reproduzindo em português o ritmo e a sonoridade da poesia (mesmo que isso soe vago), procurando simplificar soluções e evitar rebuscamento" observa ele no posfácio. Nesta passagem, todavia, o tradutor parece desconsiderar o fato de ter vez ou outra resvalado por termos como leixa-pren, conforme assinalado acima (nota 11), ou glamour, que, também sem nenhuma correspondência com o original, aparece no poema "Reflexão" (Abglanz), em que Zuleica conclui sua fala ao amado com os versos que assim soam na tradução: "Nessa rica moldura / sua imagem tem glamour: / rosas na bordadura / e uma mão de lasur". ${ }^{16}$ Pode-se apontar também, problematizando a afir-

${ }^{16}$ Quanto ao estranhamento que a palavra glamour pode provocar no leitor do poema, vale lembrar que ela começa a adquirir na língua inglesa o significado

Cad. Trad., Florianópolis, v. 41, no 3 p. 338-363, set-dez, 2021. 
mação do tradutor de ter procurado "simplificar soluções e evitar rebuscamento", para a dificuldade de se entender o verso "No olho raia a alba no lenho", na seguinte estrofe ("Livro de Zuleica"): "Tive um sonho - interpreta: / No olho raia a alba no lenho. / Diz poeta, diz profeta: / Que sonho é esse que eu tenho?" No original, é mais fácil para o leitor compreender a sintaxe desse verso em que, literalmente, "a alba resplandecia no olho através da árvore".

Observe-se ainda que reproduzir "o ritmo e a sonoridade" dos poemas do Divan goethiano - meta almejada pelo tradutor brasileiro - constitui tarefa das mais complexas, que dificilmente terá sido realizada com pleno êxito em qualquer tradução desse ciclo para outra língua. O trabalho de Martineschen destaca-se antes, e de modo admirável, pelo empenho em reproduzir os esquemas métricos e rímicos do original. Mas nesse ponto se infiltra no Divã brasileiro algo que ronda toda tradução empenhada em corresponder com rigor às estruturas formais de obras versificadas, que é o eventual afastamento, em grau maior ou menor, do "sentido" dos versos, abalando-se assim a interação original entre duas dimensões que, na concepção do poeta de Weimar, seriam inseparáveis: "Conteúdo traz a forma consigo. Forma jamais existe sem conteúdo". ${ }^{17}$

Talvez essa constatação possa ser exemplificada sumariamente com alguns exemplos, começando pelo poema que, embora não tenha sido o primeiro a ser escrito, abre o Divã: "Hégira", termo que designa a fuga de Maomé de Meca para Medina no ano 622, marcando o início de uma nova era no calendário muçulmano. É um mero detalhe, um daqueles "pequeninos nadas" (expressão de Manuel Bandeira no Itinerário de Pasárgada) que, no entanto, ganham peso considerável no universo da lírica. "Norte e oeste e sul se espalham", lê-se na tradução do primeiro verso do poema, mas

hoje corrente, e visado por Martineschen, apenas no final do século XIX.

${ }^{17}$ Gehalt bringt die Form mit. Form ist nie ohne Gehalt", como está num paralipomenon para a segunda cena "Quarto de trabalho", no Fausto I (287). A rigor, o substantivo masculino Gehalt se traduziria mais apropriadamente por "teor", que conota também a visão de mundo ou os valores envolvidos na obra, enquanto "conteúdo" corresponde mais diretamente a Inhalt. 
em Goethe o verbo é muito mais forte e expressivo do que "espalhar": trata-se de zersplittern ("estilhaçar", "esfacelar" ou "fragmentar"), com o qual se alude também às profundas rachaduras causadas no mapa geopolítico europeu por Napoleão Bonaparte, o que levou Goethe a empreender sua fuga, ou "Hégira", rumo ao Oriente de Hafez, concebido como pátria da poesia - uma $\mathrm{Pa}$ sárgada lírica, poder-se-ia dizer em alusão ao mencionado livro de Bandeira. E, fechando a antepenúltima estrofe, os versos "Ó Hafez, sem teus poemas / esta terra tem problemas" revelam-se como uma solução um tanto banal, imposta pela necessidade de rima que, resolvida aqui de forma menos feliz (com "poemas" e "problemas"), enfraquece a extraordinária condensação que Martineschen alcançara nos quatro versos anteriores da estrofe: "Nos rochedos, pela trilha, / com sua mula vai o guia; / às estrelas canta alto - / medo assoma os maus de assalto".

Enfraquecimento semelhante, e também condicionado por exigência rímica, se faz sentir no segundo poema do "Livro de Timur", o qual, dirigido a Zuleica, prepara o livro subsequente, Sukeika Nameh. Buscando fechar a terceira estrofe em rima com "ímpeto pleno", o tradutor usa o pouco expressivo "nada sereno", que soa ao leitor como mero preenchimento, em função de rima e métrica, do verso, destoando assim da vivacidade poética mantida até então: "um [mundo] que pulsa com ardores / que, em seu ímpeto pleno, / semelha muito aos amores / de bulbul, nada sereno". No original fala-se, em tradução literal, dos amores do bulbul (isto é, os amores entre o rouxinol e a rosa, frequente motivo na poesia persa, particularmente em Hafez) e do "canto que excita a alma" (seeleregenden Gesang - que decai para o complemento "nada sereno" da tradução), isto é, o canto enlevado e lamurioso do mesmo pássaro tão fortemente presente também na lírica ocidental.

E se Goethe abre seu ciclo lírico ocidental-oriental sugerindo, nos últimos versos de "Hégira", que as palavras do poeta batem suavemente às portas do paraíso demandando ingresso, em "Boa noite" - poema que fecha o "Livro do paraíso", o último do Divã encontramo-nos de fato em pleno paraíso e o poeta suplica então ao 
anjo Gabriel, que já no poema anterior embalara no sono "os sete adormecidos" de uma lenda cristã e muçulmana, que cuide agora dos "membros do exausto". O adjetivo substantivado "exausto" se refere ao "poeta", mas na tradução o leitor pode ser acometido de dúvidas ao encontrar a forma plural: "Gabriel cuide das vidas / dos exaustos, com prazer".

$\mathrm{Na}$ filologia goethiana esse "Livro do paraíso", e particularmente o poema "Superior e supremo" (Höheres und Höchstes), foi relacionado várias vezes ao final do Fausto, que mostra a enteléquia, ou o elemento "imortal", do protagonista ascendendo e volatilizando-se sob o empuxo do Eterno Feminino. Ao céu barroco e mitologicamente católico, que reina na derradeira cena "Furnas montanhosas", corresponderia o paraíso muçulmano concebido pela imaginação poética de Goethe no $12^{\circ}$ livro do Divã. E assim como o movimento ascensional com que nos deparamos no final do Fausto transcende o finis que Goethe fez seguir aos versos do Chorus mysticus, assim também a última estrofe de "Superior e supremo" sugere a dissolução da individualidade na contemplação do "amor eterno" (ewige Liebe): "nós nos desvanecemos, desaparecemos". Na tradução de Martineschen: "Livre, com quente pulsar, / um fim não encontraremos, / na visão do eterno Amar / desmaiamos, esmaecemos". ${ }^{18}$

No final do "Livro de Zuleica", o mais extenso do conjunto, o leitor da tradução brasileira se deparará com um equívoco, não de número (como em "Boa noite”), mas de gênero. Atrás de Zuleica (nome que aparece no terceiro gazel do Divã de Hafez ${ }^{19}$ ) esconde-

18 Com essa ideia do "desaparecer" (verschwinden) a filologia goethiana reforça os vínculos entre o "Livro do paraíso" e o final do Fausto. Albrecht Schöne, por exemplo, conclui seus comentários à tragédia citando as duas estrofes finais de "Superior e supremo", que culminam no motivo do "desaparecimento": no drama temos Fausto subtraindo-se misticamente à nossa vista e, no ciclo lírico, o citado verso "nós nos desvanecemos, desaparecemos", que na tradução de Martineschen se enfraquece (ou também "esmaece") com "desmaiamos, esmaecemos".

${ }^{19}$ Gazel ou gazal tem origem árabe, sendo geralmente traduzido como "teia”. O Dicionário Houaiss opta por "requebro, galanteio". Como demonstra o primoroso "Gazal em louvor de Hafiz", essa forma lírica se estrutura em dísticos com 
se, como observado acima, Marianne von Willemer e o livro que traz seu nome consiste em diálogos amorosos que a bela mulher trava com Hatem, sob cuja figura Goethe teria passado a palavra, na visão de Walter Benjamin, ao "elemento inconstante e selvagem de sua juventude" e dado "à sabedoria de mendigos, bêbados e andarilhos a forma mais elevada que jamais encontraram" (168). No diálogo entre Zuleica e Hatem - maravilhosamente impregnado de símbolos como o bulbul (rouxinol) e o hudhud (poupa eurasiática), pássaros provenientes da poesia de $\mathrm{Hafez}$ - nem sempre fica claro quem tomou a palavra. No último poema do "Livro de Zuleica", por exemplo, não se explicita quem está falando e o mesmo ocorre na sextilha anterior, que a edição brasileira não separa claramente do poema de encerramento, o qual, sem ostentar um título particular, abre-se com o verso "Em mil formas podes te esconder".

Essas "mil formas" aludem aos outros 99 nomes que a tradição muçulmana atribui a Alá. Martineschen transpõe para sua versão a monorrima presente nos versos pares do poema assim como outros detalhes do esquema rímico goethiano; contudo, ao leitor brasileiro fica a impressão de que é a mulher que se dirige ao amado, quando se trata do contrário, conforme indiciam os epítetos femininos do original, que na tradução aparecem incorretamente como masculinos: Oniamado, Onipresente, Oniviçoso, Onilisonjeiro e mais seis do tipo, até chegar na estrofe que fecha o livro: "O que sei com senso externo, interno, / tu Oni-instrutor [no original: $\mathrm{Al}$ lbelehrende, a que tudo ensina, Oni-instrutora] conheço por meio

uma mesma rima nos dois versos do primeiro dístico ("Escuta o Gazal que fiz, I Darling em louvor de Hafiz"), a qual retorna no segundo verso dos demais dísticos (em Bandeira: “diz", "infeliz”, "quis”, "sufis”, "sorris”, "Hafiz”).

No terceiro gazel de Hafez lê-se no sexto dístico, na tradução de Hammer: "Jusufs berauschende Schönheit erklärt den Zauber der Liebe, / Welcher zerrissen den Flor bei Sulicha" ("A beleza inebriante de José explica o encanto do amor / que rasgou o véu que cobria Zuleica"). Num poema do "Livro de Zuleica", Goethe faz o velho Hatem relembrar seu jovem predecessor José no amor da moça: "Que Zuleica por José foi encantada / não é nada novo; / era moço, graça de quem é novo; / era belo, dizem, era de encantar; / era bela, podiam se deleitar". 
de ti; / e quando os nomes de Alá, cem, externo, / em cada um ressoa um nome de ti".

\section{Globalização e Literatura Mundial}

De todo modo, soluções mais discutíveis ou mesmo eventuais equívocos que possam ser apontados no Divã ocidento-oriental (e facilmente sanáveis para uma próxima edição) em nada diminuem os méritos extraordinários de uma tradução a que o próprio Goethe não deixaria de prestar reconhecimento. Numa carta que enviou em janeiro de 1828 ao escocês Thomas Carlyle, que quatro anos antes publicara sua tradução dos Anos de aprendizado de Wilhelm Meister, o poeta lança mão do vocabulário do comércio, que ele via em processo de crescente globalização, para valorizar o papel do tradutor na constituição de uma literatura também cada vez mais globalizada, a que ele chamou Weltliteratur. Pois apesar de suas insuficiências intrínsecas, a tradução é vista por Goethe como "um dos negócios mais importantes e dignos na movimentação geral do mundo". E em seguida, o epistológrafo recorre ao mesmo campo metafórico que nos anos anteriores havia impregnado seu Divã: “O Alcorão diz: 'Deus deu a todo povo um profeta em sua própria língua'. Assim todo tradutor é um profeta para seu povo”.

Disponibilizando ao leitor brasileiro a primeira tradução integral em língua portuguesa do intenso diálogo poético do autor do Fausto com a tradição árabe e persa, Martineschen oferece ao mesmo tempo uma contribuição inestimável à nossa cultura - um feito que se mostra tão mais notável à luz de seu empenho em reproduzir com rigor a estrutura formal dos poemas alemães - ao contrário, por exemplo, da tradução espanhola de Rafael Cansinos Assens.

Fazer com que Hatem e Zuleica dialoguem em português em "igual palavra e som", não apenas "olhar a olhar", mas também "rima a rima" - como diz o poema "Bahram-Gor, dizem, inventou a rima" - representa um objetivo para cuja magnitude o próprio Goethe de certo modo chamou a atenção ao discorrer sobre as 
vantagens de uma tradução em prosa, como meio para se contornarem as imensas dificuldades de uma tradução em versos. Já nas "Notas e ensaios" que acompanham seu Divã, por exemplo, o poeta lamenta que a Canção dos Nibelungos (início do século XIII), redigida em alto-alemão médio (Mittelhochdeutsch) e em estrofes de quatro versos rimados em parelha (chamada justamente "estrofe dos Nibelungos"), não tivesse sido traduzida para o alemão moderno numa "prosa útil", o que teria propiciado ao leitor uma fruição desse heroico épico medieval em "toda a sua força”. Também numa conversa com Eckermann sobre canções sérvias, datada de 18 de janeiro de 1825, Goethe sugere que os encantos dos versos populares eslavos transpareceriam numa simples tradução em prosa de seus "motivos" (142-143). Sobre essa questão da traduzibilidade de versos manifestaram-se, como sabido, grandes nomes da Literatura Mundial, e já Dante, cinco séculos antes de Goethe, negava a possibilidade de se preservar "toda a doçura e harmonia" de uma criação em versos ao traduzi-la para outra língua: E pèro sappia ciascuno che nulla cosa per legame musaico armonizzata se puó de la sua loquela in altra transmutare sanza rompere tutta sua dolcezza e armonía. ${ }^{20}$ E Cervantes, no "escrutínio" que o padre e o barbeiro realizam na biblioteca de D. Quixote, faz o primeiro considerar com ceticismo a possibilidade de se traduzirem versos, que por mucho cuidado que pongan y habilidad que muestren, jamás llegarán al punto que ellos tienen en su primer nacimiento. ${ }^{21}$

Daniel Martineschen, felizmente, não se deixou guiar por semelhantes concepções e, com isso, seu Divã ocidento-oriental oferece ao leitor preciosos exemplos da arte tradutória in the realms of

\footnotetext{
${ }^{20} \mathrm{Na}$ tradução de Emanuel França de Brito: "Por isso, saibam todos que nada do que é harmonizado por um enlace musaico pode ser traduzido da sua língua para outra sem que se quebre toda a sua doçura e harmonia" (Dante 123) Em nota referente ao adjetivo "musaico", o tradutor cita comentadores que o entendem tanto no sentido de "poético" (relacionado à "musa" da poesia) como de "musical". ${ }^{21} \mathrm{Na}$ tradução de Sérgio Molina: "pois, por mais cuidado que ponham e habilidade que mostrem, jamais alcançarão o ponto que eles têm no seu primeiro nascimento" (Cervantes 100).
} 
gold, como John Keats (On first looking into Chapman's Homer) chamou o "reino da poesia". Primorosas, por exemplo, são as três quadras em redondilha menor do poema "Aparição", o qual, imantado pelo símbolo do arco-íris não só colorido, mas também branco (por trás do qual se oculta, como na imagem epistolar citada na abertura deste texto, a teoria goethiana das cores), culmina na estrofe: "Tu, velho querido, / não deves chorar; / teu cabelo é embranquecido, / mas tu vais amar". Igualmente sóbria e admirável é a tradução do "Livro de leitura", inspirado em poemas que Goethe - também o poeta cometeu seus deslizes e cochilos... - atribuiu ao persa Nezami (1141 - 1209), mas na verdade provenientes do poeta turco Nischani (século X): "Maravilhoso livro dos livros / é o livro do amor! / Atencioso eu o li: / pouca folha de alegria, / cadernos todos de dores; / uma seção faz a separação. / Reencontro! Um só capítulo, / fragmentário. Tomos de mágoa / alargados com explicações, / infindas, sem medida".

O leitor que percorrer as páginas desse primeiro Divã goethiano em língua portuguesa estará palmilhando os caminhos e jardins de uma Chiraz que o "gêmeo" de Hafez amalgamou às paisagens renanas, resultando dessa fusão uma utopia de elevada poesia, envolta pelo canto do bulbul e do hudhud, mensageiro amoroso já nos tempos "do rei Salomão e da rainha de Sabá" (poema "Saudação", no "Livro do amor"), e sabendo ainda a denso odor de rosas, jasmins e do vinho celebrado em incontáveis versos. Ao leitor brasileiro descortinar-se-ão poemas regidos pelo princípio da "polaridade", de fundamental importância tanto para a obra científica quanto literária de Goethe. E à polaridade ocidental-oriental que transparece no título da coleção associam-se várias outras, começando com a polaridade amorosa: felicidade em poucas "folhas" e sofrimento em muitos "tomos"; o paraíso da poesia e o pesadelo da história: "tronos racham e impérios estremecem", o que pode ser relacionado ao posterior paralelo entre o inverno de Napoleão na Rússia e o de Timur (Tamerlão) na China em 1405; o êxtase sensível do vinho e a visão sufista de Deus; juventude (Zuleica) e velhice (Hatem); vida e morte: "morre e te transforma!"; unidade 
e duplicidade: "não vês tu nestas canções / que sou Um e duplicado?"; ou ainda, para citar mais um exemplo, a "polaridade" corporal que deve inspirar gratidão ao ser humano, sístole e diástole, o inspirar e o expirar: "Existem duas graças no respirar: / sorver o ar, dele se liberar. / Um refresca, o outro oprime: / a vida é assim, mista e sublime. / Graça a Deus, se ele te aperta; / dá graça a Ele se te liberta".

Ao discorrer em sua Estética (no segmento "O panteísmo da arte") sobre a "poesia muçulmana", Hegel delineia por fim um paralelo entre os "Divãs" de Hafez e de Goethe, observando que os poemas ocidental-orientais publicados em 1819 só puderam nascer graças à profundidade e ao frescor juvenil do espírito goethiano, também "a um sentido que se espraiou pela mais ampla latitude, seguro de si em todas as tormentas", assim como - e Hegel cita então versos do poema "A Zuleica" - graças a "um [mundo] que pulsa com ardores / que, em seu ímpeto pleno, / semelha muito aos amores / de bulbul [...]". Na perspectiva desse espraiamento "pela mais ampla latitude", torna-se procedente afirmar que o mergulho na tradição poética do oriente árabe e persa, sobretudo na obra de Hafez, desempenhou papel crucial na concepção de uma Weltliteratur destinada a ocupar lugar cada vez mais relevante no mundo globalizado. No contexto da então emergente Literatura Mundial - ou de uma Poesia Mundial (Weltpoesie) - os poemas haveriam de fecundar-se e renovar-se mutuamente em meio a uma "dança das esferas, harmônica no tumulto", nos versos que colocam ao lado da harpa do rei Davi e do bulbul persa uma colorida serpente brasileira, evocada por uma canção em língua tupi na imagem de um "cinto" que esplandece como dádiva amorosa:

Como Davi entoou a harpa e o canto principesco,

A canção da viticultora soou docemente junto ao trono,

$O$ bulbul do persa envolve o canteiro de rosas

E pele de serpente esplandece como cinto indígena,

De polo a polo, canções se renovam,

Uma dança das esferas, harmônica no tumulto; 
Deixai que todos os povos sob o mesmo céu

Animados se regozijem nas mesmas dádivas. $(271)^{22}$

Duzentos anos após Goethe ter ofertado à Literatura Mundial seu mais extenso ciclo lírico, a tradução de Daniel Martineschen descortina aos leitores brasileiros a possibilidade de se regozijarem nesses poemas ocidental-orientais que celebram a fecunda interação entre duas grandes tradições literárias: "Grandioso o Oriente / o Mediterrâneo cruzou; / Quem ama Hafez e o entende / sabe o que Calderón cantou", conforme celebra essa quadra do "Livro dos Provérbios", Hikmet Nameh, o sexto dos doze livros enfeixados no Divã.

Por trás desse entusiasmo por Hafez e Calderón está o trabalho dos tradutores Hammer-Purgstall e, no tocante ao dramaturgo espanhol, A. W. Schlegel (El príncipe constante), F. H. Einsiedel (La vida es sueño) e, sobretudo, Johann D. Gries, de cuja pena (e sob o incentivo de Goethe) advieram outras 13 peças calderonianas em roupagem alemã, comentadas pelo poeta em resenhas, conversas e cartas, como na enviada ao velho amigo Carl Ludwig Knebel (1744 - 1834) em 13 de junho de 1821: "Não deixarei de enaltecê-las [as traduções de Gries] diante de Calderón, quando encontrá-lo no além". Trata-se aparentemente de um mero gracejo, mas de um "gracejo muito sério", na expressão (diese sehr ernsten Scherze) com que o velho Goethe se referiu algumas vezes ao Fausto II, deixando transparecer profundo respeito pelo ofício do tradutor, um dos "mais importantes e dignos na movimentação geral do mundo", como formulado na mencionada carta de janeiro

${ }^{22}$ Redigido em 1827, esse poema foi publicado postumamente na Edição Cotta das obras de Goethe em 40 volumes sob o título Weltliteratur. Com o verso "E pele de serpente esplandece como cinto indígena", Goethe remete ao poema Liebeslied eines Wilden ("Canção de amor de um selvagem"), que canta os anéis coloridos de uma cobra coral. Goethe escreveu esse poema em sua juventude, inspirado pelo ensaio de Montaigne "Des Cannibales", e o retomou 43 anos mais tarde dando-lhe então o título Brasilianisch (desenvolvi alguns comentários sobre esses poemas "brasileiros" de Goethe no ensaio "Natureza ou Deus: afinidades panteístas entre Goethe e o 'brasileiro' Martius”: Revista Estudos Avançados. 24. 69 (mai/ago 2010): 183 - 202). 
de 1828 a Carlyle. Outro eloquente testemunho dessa postura de respeito e admiração encontra-se nas "Notas e ensaios para uma melhor compreensão do Divã", que em seu antepenúltimo capítulo levantam um monumento ao tradutor dos poemas - gazéis, ruba'is, cássidas - de Hafez, perante os quais o poeta alemão se vê compelido a envolver em modéstia seu próprio ciclo ocidental-oriental: "O quanto passei a dever a este homem honrado é demonstrado no meu livrinho em todas as suas partes". Se o aprofundamento na tradição poética e cultural do Oriente proporcionou a Goethe um fundamento essencial para desenvolver a ideia de Literatura Mundial, então podemos concluir de maneira simples e concisa postulando que, sem a consideração e correspondente valorização do trabalho dos tradutores, essa ideia não poderia ter sido concebida.

\section{Referências}

Alighieri, Dante. Convívio. Tradução de Emmanuel França de Brito. São Paulo: Companhia das Letras, 2019.

Barrento, João. "Poesia. A glorificação do sensível”. Revista Estudos Avançados, 33. 96, mai/ago (2019): 317 - 337.

Benjamin, Walter. "Goethe". Tradução de Irene Aron e Sidney Camargo. Ensaios reunidos: Escritos sobre Goethe. Marcus Vinicius Mazzari (Ed.). São Paulo: Duas Cidades/Editora 34, 2009.

Campos, Haroldo de. Deus e o diabo no Fausto de Goethe. São Paulo: Perspectiva, 2005.

Cervantes, Miguel de. O engenhoso fidalgo D. Quixote de La Mancha (Primeiro Livro). Tradução de Sérgio Molina. São Paulo: Editora 34, 2002. 
Eckermann, Johann Peter. Conversações com Goethe nos últimos anos de sua vida. Tradução de Mario Luiz Frungillo. São Paulo: Editora UNESP, 2016.

Goethe, Johann Wolfgang v. De minha vida. Poesia e verdade. Tradução de Maurício M. Cardozo. São Paulo: Editora UNESP, 2017.

Goethe, Johann Wolfgang v. Divã ocidento-oriental. Traduzido por Daniel Martineschen. São Paulo: Estação Liberdade, 2020.

Goethe, Johann Wolfgang v. Faust I. Werke. Weimarer Ausgabe. Munique: DTV, 1987. 14 v.

Goethe, Johann Wolfgang v. Goethes Werke. Organizado por J. G. Cotta. Stuttgart; Tübingen: $1840.2 \mathrm{v}$.

Goethe, Johann Wolfgang v. "Ilimitado". Fevereiro. 7 (2014). Revista Fevereiro. Disponível em: http://www.revistafevereiro.com/pag.php?r $=07 \& \mathrm{t}=16$.

Goethe, Johann Wolfgang v. Obras completas. Editado por Rafael C. Assens. Madrid: Santillana/Aguiar, 2004. 3 v.

Goethe, Johann Wolfgang v. Os Sofrimentos do Jovem Werther. Tradução de Cláudia Dornbusch. Rio de Janeiro: Antofágica, 2020.

Goethe, Johann Wolfgang v. Tag- und Jahreshefte. Autobiographische Schriften. Goethes Werke. Hamburger Ausgabe. Munique: DTV, 1988. 10 v.

Goethe, Johann Wolfgang v. West-östlischer Divan. Editado por Hendrik Birus. Frankfurt: Deutscher Klassiker Verlag, 2010.

Goethe, Johann Wolfgang v. Wilhelm Meisters Wanderjahre. Hamburger Ausgabe (v. 8: Romane und Novellen II - organizado e comentado por Erich Trunz). Munique: DTV, 1998. $14 \mathrm{v}$.

Hegel, Georg Wilhelm Friedrich. Ästhetik. Berlim e Weimar: Aufbau Verlag, 1976. 2 v. 
Mazzari, Marcus. "Natureza ou Deus: afinidades panteístas entre Goethe e o 'brasileiro' Martius”: Revista Estudos Avançados. 24. 69 (mai/ago 2010): 183 $-202$.

Mazzari, Marcus. "'O humano que jamais nos abandona'. A obra epistolar de Goethe”. Revista Estudos Avançado. 33. 96, mai/ago. (2019): 225-252.

Müller, Kanzler v. Unterhaltungen mit Goethe. Editado por Ernst Grumach. Weimar: H. Böhlaus Nachfolger, 1959.

Recebido em: $12 / 05 / 2021$

Aceito em: 23/08/2021

Publicado em setembro de 2021

Marcus V. Mazzari. E-mail: mazzari@usp.br. ORCID: http://orcid.org/00000002-8335-954X. 